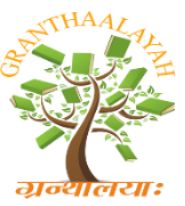

$$
\begin{gathered}
\text { INTERNATIONAL JOURNAL OF RESEARCH - } \\
\text { GRANTHAALAYAH } \\
\text { A knowledge Repository }
\end{gathered}
$$

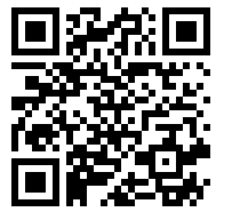

Social

\title{
FACTORS RESPONSIBLE FOR THE POOR READING ACHIEVEMENT OF PUPILS IN PUBLIC PRIMARY SCHOOLS FROM TEACHERS' PERSPECTIVES: A CASE STUDY OF YOLA SOUTH AND NORTH LOCAL GOVERNMENT AREA OF ADAMAWA STATE
}

\author{
Elizabeth Raymond ${ }^{* 1}$ \\ ${ }^{* 1}$ American University of Nigeria (AUN)
}

\begin{abstract}
The main purpose of the study is to gain an understanding of the factors responsible for the poor reading achievement of pupils in public primary school in Yola South and North Local Government area of Adamawa state from teachers' perspectives using a qualitative phenomenological approach. A total of 20 teachers were selected from ten randomly selected schools within Yola North and South Local Government Area. Two teachers represented each school. A set of semi-structured interview questions were used to gather data from the participant. Six major themes emerged from the analyzed data. The main themes that emerged from the data analysis are lack of commitment of teachers to their responsibilities, teachers lacking the skills to teach phonics and foundational skills in reading, lack of instructional and learning materials. Other emerging issues are related to inadequately qualified teachers, the influences of the socioeconomic status of parents on their negative attitude towards the education of their children as well as the interference/adverse effects of mother tongue on language learning. The findings from this study will help the government and educators push for policies that would help improve the academic performances of students in the state.
\end{abstract}

Keywords: Reading Achievement; Emerging Issues; Qualitative Phenomenological Approach; Semi-Structured; Mother Tongue; Reading Skills.

Cite This Article: Elizabeth Raymond. (2019). "FACTORS RESPONSIBLE FOR THE POOR READING ACHIEVEMENT OF PUPILS IN PUBLIC PRIMARY SCHOOLS FROM TEACHERS' PERSPECTIVES: A CASE STUDY OF YOLA SOUTH AND NORTH LOCAL GOVERNMENT AREA OF ADAMAWA STATE." International Journal of Research Granthaalayah, 7(5), 208-229. https://doi.org/10.29121/granthaalayah.v7.i5.2019.841.

\section{Introduction}

Students need to have the necessary literacy and reading skills to succeed in schools as reading is an essential skill used to master other subjects taken in the Nigeria schools (Adeniji, 2010; Geske 
\& Ozola, 2008; Cimmiyotti, 2013). Early acquisition of literacy skills is a critical phase in a primary school pupil's life and should be an essential goal for educators at the primary level (Reutzel 2015). The ability to read help students access and understand information from their texts. It is suggested that students with poor reading skills might continue to struggle with reading and comprehension even at the secondary level if they do not receive appropriate intervention at the primary school. Research on literature suggests that acquisition of essential reading and comprehension skills give primary school students a strong background to succeed at the secondary schools' level (Tong et al., 2011; Pfost et al., 2012; Elwér, 2014). Reading at grade level influences the students' success in other subjects and it is a substantial factor that affects grade level performances.

In Nigeria, the English language is used as the means of communication, and it is also used to instruct students in the classrooms. Adamawa state is located in the Northeastern part of Nigeria. As an educator in Adamawa state seeing students graduate from the primary schools with poor reading proficiencies is worrisome. NPC and RTI International, statistical data indicated that the Northeastern part of Nigeria ranked the lowest in educational achievement at both the primary and secondary level. Research on literature has identified some factors that may be responsible for poor reading performances amidst primary school pupils in Nigeria and some other part of the global (Dunne et al., (2013) in their work identified factors like poor reading and comprehension skills as one of the significant factors causing poor academic performances in schools in the Northeastern Nigeria. What previous studies did not explore is to find out the perspectives of teachers on the factors responsible for poor reading performance among primary school students in Adamawa state. This formed the research objective.

\subsection{Background of the Study}

Reading at grade level is an essential skill to primary school leavers who are prepared for a successful secondary school education. It is evident from past work and statistical findings that a significant percentage of students leave the primary school without possessing the basic literacy and comprehension skills (UNESCO, 2013). The literacy level of primary school students in Adamawa state is considered to be low because it is only about $40 \%$ of ages six to adulthood that possesses basic literacy skills. According to statistical data, Adamawa state with the other states within the Northeastern region ranked the poorest in academic performances of primary and secondary school students. The findings from this research will help the educators gain an understanding of how to help our students increase their academic achievement. It is also one of the states whose educational sector suffered from Boko Haram Insurgency.

The Boko Haram is a terrorist group that is against formal education in Nigeria (Amnesty International, 2013). Their activities led to the kidnapping of primary and secondary school students and the destruction of school properties (Abdulraheed et al. 2015) "Boko Haram" means Western education is forbidden. Several factors are perceived to be responsible for the poor reading and academic achievements of primary school students in the region. This research sought to understand the factors that may be responsible for the poor reading performance of public primary school students from teachers' perspectives using a qualitative approach and reported the findings. 


\subsection{Related Work}

This section is organized to present the themes that give some understanding of the topic under study. Some of the identified themes include the connection between reading performances and achievements in other subjects, the influence of mother tongue on reading achievement, the relationship between teachers' classroom practices and students' reading achievement and professional development and reading achievement of students. Reading at grade level is an essential skill to primary school leavers who are prepared for a successful secondary school education. It is evident from past work and statistical findings that a significant percentage of students leave the primary school without possessing the basic literacy and comprehension skills. The literacy level of primary school students in Adamawa state is considered to be low because it is only about $40 \%$ of ages six to adulthood that possesses basic literacy skills.

According to statistical data, Adamawa state with the other states within the Northeastern region ranked the poorest in academic performances of primary and secondary school students. Some of the factors such as terrorism (Boko Haram). Adamawa is also one of the states whose educational sector suffered from Boko Haram Insurgency. The Boko Haram is a terrorist group that is against formal education in Nigeria (Amnesty International, 2013). Several factors are perceived to be responsible for the poor reading and academic achievements of primary school students in the region. This research sought to understand the factors that may be responsible for the poor reading performance of public primary school students from teachers' perspectives.

\section{Material and Methods}

This section of the study examined how the research data was constructed, collected and interpreted. The section also described the statistical instruments used for data collection and analysis. The population that participated in the study were also highlighted in this section. Adamawa State is predominantly a Hausa speaking state occupying a land space of about 36,917 square kilometres. It is bordered by the states of Borno to the northwest Gombe to the west and Taraba to the southwest. Its eastern border forms the national eastern border with Cameroun. This study was delimited to ten public primary schools in Yola North and South local government area of Adamawa state. Twenty teachers were interviewed with two teachers (one male, one female) representing each school. No financial compensation was given to the interviewees during the interview section. The study was delimited to twenty teachers to enable the researcher to get rich data from the face to face interview sessions. Before the interview, consent forms were signed by the principles and participants in each of the schools.

The methodology used to carry out this research was based on epistemological approach. Maynard, (1994) described epistemology as a way of providing a philosophical foundation for the possible knowledge and ensuring that the knowledge is valid. Epistemologically, this research is influenced by the constructivist paradigm. Constructivistically, it is believed that individuals gain a better understanding of the world by developing meaning from their experiences and the varied experiences of others. This research tends to understand the meaning of the situation under study through interaction and discussion with the research participants. The constructivist paradigm accentuates that knowledge is produced when a researcher strives to understand the social world of the participants focusing on the participants' meaning and interpretation. The choice for constructivist paradigm in this study is to gain a better understanding of the factors influencing the 
reading performances of primary school students in Adamawa state from the viewpoints of the primary school teachers.

\subsection{Research Design}

The study used a phenomenological inquiry in qualitative research method to understand teachers' perspectives of the factors that influence the reading abilities of primary school students in Yola South Local Government of Adamawa State. Qualitative research gives the researcher an opportunity to interact with the participants in the natural setting where the participant is experiencing the issue under study (Creswell, 2014; Creswell, 2007). It is also a recommended approach when a researcher needs to explore the feelings and perception of the participants. It gives the researcher an opportunity to gain a deeper understanding of the participant's perception of the situation under study. The phenomenological inquiry aims to report the point of view of the individual participants in the study, and it is carried out through a thorough interview process.

\subsection{Sample population and Description}

The study used simple random sampling to select the ten schools from a total of 92 public primary schools located in Yola North and South local government area. In simple random sampling, every school in the two local government areas has an equal chance of being picked. Based on the suggestions by Cohen et al., (2008) the names of the 92 schools were each written on a piece of paper and placed in a container, and ten names were randomly picked from the container. The ten schools randomly picked became the sample population. For the qualitative study, twenty teachers were purposely picked. Marshall, (1996) explained that qualitative research sampling should be purposeful and flexible in order to get rich and quality data. Judgment sampling method was used by the researcher to purposely select 20 teachers from the ten schools (Marshall, 1996).

Judgment sampling according to Marshall, (1996) is purposeful and involves developing variables that might influence the selection of the participants in order to get rich data. The researcher purposely selected twenty teachers that have five to over thirty years of teaching experience from the forty teachers that volunteered to participate in the study by politely asking the intending participants their years of teaching experiences and letting them know they will be contacted as soon as possible. Twenty participants were contacted by the researcher to fix a date for a face to face meeting with the researcher. The venue for the meeting was jointly agreed. Purposefully selecting participant is a strategy recommended by and Creswell, (2014) for the collection of rich data. The researcher assumed that long-serving teachers would have richer data to share with the researcher during the interview process. Posters flyers were placed on the walls of each of the chosen schools for two weeks. The flyers provided information about the purpose of the research, the assurance of anonymity of the participants and the researcher contact number. Forty intending participants called the researcher within two weeks. Before this, letters were sent to the Head of schools seeking for permission to place posters on their school walls. All of the Head of schools gave permission for the posters to be placed on their school walls. 


\subsection{Research Setting}

The researcher, after receiving telephone confirmation from prospective participants, initiated the first meeting with each of the participants for an orientation/induction session. The orientation sessions started on the 29th of May 2017 and the last orientation session took place on the 1st of June 2017. The meeting took place in various locations mutually agreed by both the researcher and the intending participants. The first session was used for familiarization, clarification of the purpose of the research study and the explanation of the content of the consent form. The researcher gave the consent forms to the intending participants and agreed to come after two weeks for the forms. The researcher communicated clearly to the participants of their right to refuse signing the consent form if they do not want to be part of the study.

Details of the information on the consent form can be found in Appendix A. All the participants signed the consent forms. Dates and venue for the interview sessions were jointly fixed. The participants were more comfortable to have their respective interview sessions in their houses. The researcher scheduled the interview session date based on the date set by the participants. The first interview session took place on the 14th of June while the last interview session was on the 17th of July 2017. All the sessions took place at the residences of the twenty participants. Creswell, (2014) suggested that a site free from distraction should be selected purposely for a qualitative interview session. The interview session was a one-time in-depth session lasting one hour to one and a half hour.

\subsubsection{Interview Sessions}

Interview sessions in qualitative research enable the participants to share their experiences and point of views on the subject under study and it gives the researcher an opportunity to explore and understand the participants' viewpoints (Punch, 2009; Gill et al. 2008). Semi-structured interviews were used to gather data for the study and also, probing questions were asked for a better understanding of the participants' perspective. According to Jamshed, (2014), semi-structured interviews are organized around some preplanned set of open-ended questions and an interview guide is used to present the questions in order to elicit rich data during the interview sessions. A face to face interview session was conducted in an extensive interactive one-time session that lasted for a one hour to one and a half hour.

The interview questions can be found in Appendix C. The researcher developed the interview questions from the research project questions. The researcher demonstrated the ability to listen keenly to what was said by each participant. Seidman, (2013) commented that actively listening to the participants' talk helps the researcher gain a better understanding of what is being said and also gives the researcher a direction on the follow-up question to ask the participant. The data collected was handwritten, and also audiotaped. Nightly, the researcher listened to the tape to capture things missed in the hand written notebook. The interview notes were photocopied, and a copy is kept safely. 


\subsubsection{Interview Data Analytics}

One of the aims of a qualitative data analysis according to Flick, (2014) is to describe the lived experiences of the sample populations in detail by organizing and explaining the linguistic data. The study purposely selected twenty teachers' participants that had five years and above teaching experience. Forty teachers volunteered through a telephone call, but twenty of them were selected based on a purposeful selection. Purposefully choosing participant is a strategy recommended by Creswell, (2014) for the collection of rich data. Figure 1 show the years each participant has taught in the public school.

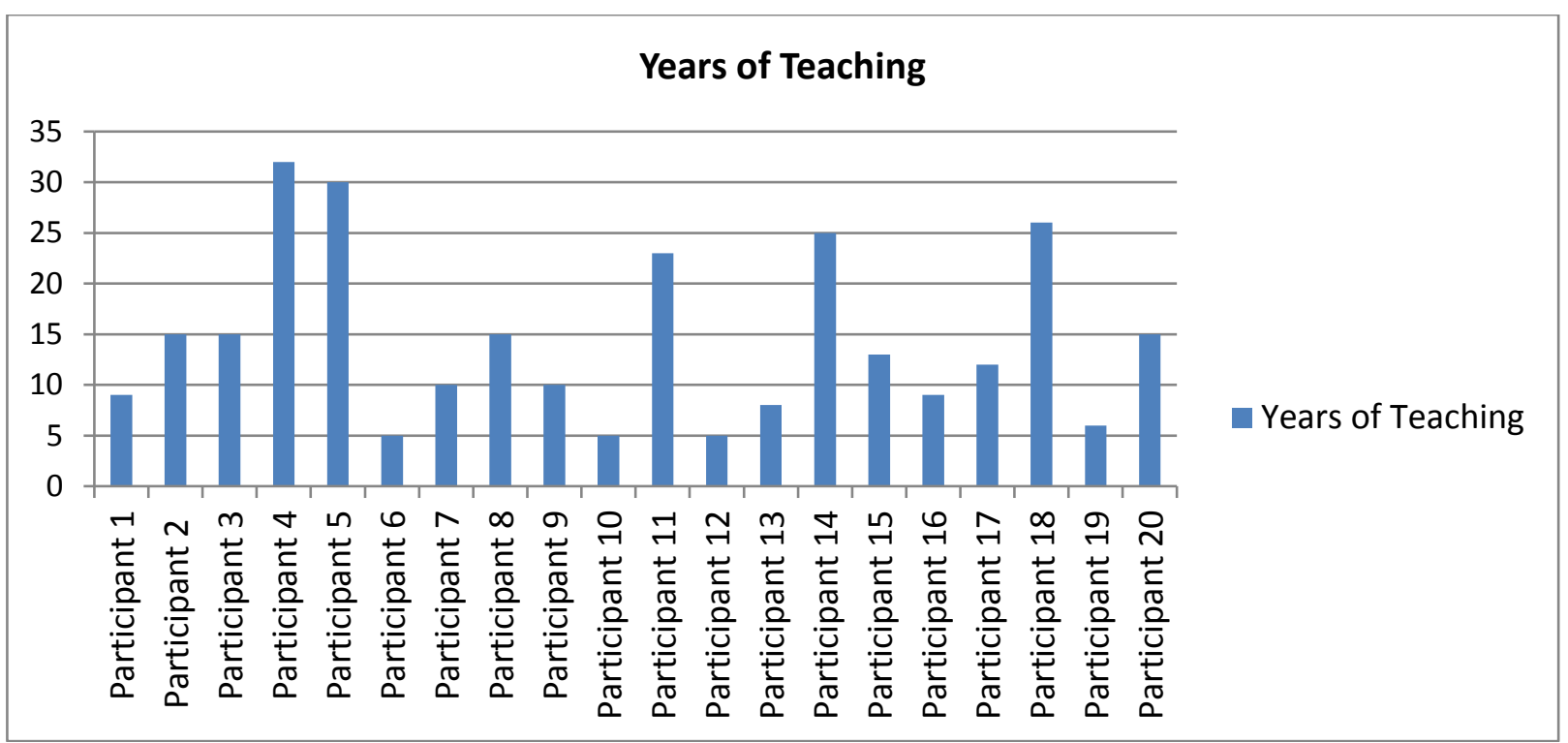

Figure 1: The participants' response to question four

The following steps suggested by Saldana, (2013); guided the systematic analysis of the data during the interview.

- The interview notes were read repeatedly, and the audio tape recording was also listened to again and again to find patterns, meanings, and sentences with similar meaning.

- The transcribing of the audio tape recording was correctly and adequately done.

- Significant words and phrases were coded.

- Themes were identified and reviewed.

- The identified themes were shared with the participants through a regular visit to ensure that viewpoints were represented correctly.

- Finally, the researcher used the developed themes to provide narration which attempted to present the perspectives of the participants. The researcher used numbers in identifying the participants in no particular order because of the commitment of the researcher to ensure that the identity of the participants is not linked to the study as agreed in the consent form signed by the participants. According to Vogt et al. (2014) codes are phrases or words that capture significant phrases from interview transcripts, field notes, documents, etc. that would be categorized based on a repetitive pattern. A theme according to Saldana, (2013) is a short sentence or phrase that brings meaning to a repetitive pattern in data. 


\section{Results and Discussion}

The results for this discussed below is classified under themes and factors responsible for poor reading achievements among primary school pupils in Adamawa state.

\subsection{Themes Emerged from the Study}

\subsubsection{Theme One: Lack of Commitment of Teachers to Their Responsibilities}

Lack of commitment to the teaching profession is regarded as one of the factors responsible for poor reading achievement of primary school students in the state. All of the participants during the interview session believed that teachers in the public schools in Adamawa state lack commitment to their teaching job because their salaries are not paid regularly, and this discourages them from giving their best. This factor is in line with findings from other studies that indicated the existence of a significant relationship between teachers' commitment and the academic performances of their students (Cornelius-Ukpepi, 2012; Kiplagat, 2012; Abudu \& Gbadamosi, 2014; Denessen et al., 2015).

The study is validated by a study carried out by Cornelius-Ukepepi, (2012) who used a quantitative research approach to investigate the relationship between teachers' commitment and students' academic performances. The findings indicated that there is a significant relationship between teachers' commitment and students' academic performances. From the findings, irregular payment of salaries had a strong impact on teachers' commitment and motivation. This finding is also validated by the study of Oredein and Awodun, (2013) who used a descriptive survey to investigate the effect of teachers' motivation on science students' academic performance in Nigeria secondary schools. The study population was 510 teachers and 6,800 students who represented the total number of senior secondary school's science teachers and students in two states in the western part of Nigeria. The result of the descriptive survey indicated teachers' salaries as the strongest motivator of teachers, and it has a strong potential to impact students' performance negatively. Ofoegbu, (2004) in a similar study used a descriptive survey instrument to investigate the impact of teachers' motivation in the classroom and school improvement. 772 teachers from the public secondary and primary school from the eastern part of Nigeria participated in the research study. The finding indicated that teachers' motivation has an impact on teachers' classroom effectiveness and regular payment of salaries was indicated as a strong motivating factor. The findings from this research resonate with similar findings from the other regions in Nigeria that irregular payment of salaries has an impact on the commitment of teachers.

\subsubsection{Theme Two: Teachers Lack the Skills to Teach Phonics}

Phonics instruction is used to help students relate the sounds in spoken words to written words. Ma \& Crocker, (2007, p.53) defined phonics instruction as the systematic approach to helping students to understand the relationship between the "individual sounds of spoken language and the letters of the written language." Ten of the participants see a lack of phonics instruction, especially at the lower primary school level as one of the factors responsible for poor reading achievement of primary school students in Adamawa state. Findings from some studies have indicated that 
phonics instruction is necessary at the primary level of education and it is regarded as one of the tools that help students master how to read.

Additionally, seven teachers who teach at the upper primary school (Primary 4 to 6) said that one of the reasons students cannot read at the Upper Primary school level is because they lack foundation in phonics. Research has identified the acquisition of phonics skills by the students in the early years of schooling as one of the key factors that enhance the reading skills of students. National Research Panel, (2004) used a quasi-experimental design approach to find out if instruction in phonics enhanced the reading skills of students. The findings revealed that the students that received phonics instruction applied the skills in reading and they did better than children who did not receive instruction in phonics. From research findings, phonics is one of the critical skills that enhance reading performances. Similar studies in Nigeria also indicated the positive impact phonics instruction has on students' reading ability. Don-Ezenne (2014) used a descriptive survey design to test 83 students' word recognition and pronunciation ability at Junior Secondary school. The result revealed that students performed poorly in the administered test. This finding agreed with an earlier study by Okebukola, (2009) who used a quasi-experimental design to find out if there was a significant difference between two groups of emergent readers. The experimental group was exposed to phonics instruction and was taught different phonics skills while the control group was taught by the school English teacher who used the conventional method to teach the students. The finding revealed that the experimental group performance in the administered test was significantly higher than that of the control group.

In the Nigerian National Policy on Education document, English language is recommended to be used as a medium of instruction from Primary Four through Secondary school but should be taught as a social subject in Primary one through three. Also, teachers' professional training has been indicated in some studies to improve teachers' classroom practices and quality (Akpan and Ita, 2015). Alade and Odebode, (2013) examined the impact teachers' professional development had on students' academic achievement in Math, English, and Biology in public secondary schools in Lagos. The findings revealed that students' performances in these subjects increased and teachers' quality improved. Amadi, (2013) study suggested that continuous training of teachers to equip them with current and emerging instructional techniques will have a significant impact on students' academic performance.

\subsubsection{Theme Three: Lack of Instructional and Learning Materials}

Twelve participants mentioned that the lack of instructional materials in their classrooms during teaching and learning process is one of the factors responsible for the poor performance of primary school students in Adamawa state. Olayinka, (2016) used a quasi-experimental design to find out if there was a significant difference between the performance of students in a control group and an experimental group in a social studies curriculum. Essential instructional materials that would enhance the teaching of social studies were used for teaching the participants in the experimental group while the control group was taught with the use of the conventional teaching method without the use of instructional materials. The findings indicated that the experimental group performance in an achievement test was significantly better than the performance of the students in the control group. Findings from studies carried out in other regions in Nigeria reported that instructional materials have a significant impact on students' academic performances (Olayinka, 2016). 


\subsubsection{Theme Four: Inadequately Qualified Teachers}

The interview findings indicated that there are a good number of people teaching in the primary schools in Adamawa state who are not professional teachers. Fifteen of the participants see a lack of qualified teachers in the system as one of the factors responsible for the low performance of students in the primary schools in Adamawa state. According to the participants, the primary schools also lack a sufficient number of English teachers. The finding is validated by previous studies that indicated that teacher's qualification has a significant influence on the performances of students. Fakeye, (2012) used a descriptive survey design to investigate the impact of teacher's qualification and mastery of subject on the academic achievement of students in the English language. 1000 students selected from 20 senior secondary schools participated in the study. The result indicated that teacher's qualification and mastery of subject has a substantial impact on the academic performances of students. In a more recent study, Oselumese and Omoike, (2015) used a descriptive survey design to investigate the impact of teacher's qualification on the performance of students in public secondary schools in Nigeria. 1348 teachers were selected from 598 public schools in Edo state to participate in the study. The finding agrees with previous studies that revealed the impact of teachers' qualification and mastery of subjects on the academic achievements of students at both the primary and secondary level of education. Employing teachers that are qualified to teach English studies would improve the reading achievement of primary school students in Adamawa state.

\subsubsection{Theme Five: Socioeconomic Influence}

Most of the participants believe that parents' attitudes towards the education of their children are poor and this is affecting the academic performance of their children. Some of these attitudes reflect in the parents not buying the required textbooks for their children, especially English and Mathematics textbooks. Also, some of the children come to school hungry, and some of them are made to help in their parents' petty trading instead of going to school. The impact of socioeconomic status of parents on the education of their children can be assumed to have a significant impact on the academic achievement of their children. The findings revealed that parents with higher socioeconomic power could provide their children with necessary school supplies and also create a conducive learning environment at home. The study also showed that parents with low economic power could hardly offer their children with the necessary school supplies and this can hurt the performance of their children at school. Onyancha et al. (2015) in a similar study used a descriptive survey design to investigate the influence of socioeconomic status of parents have on the academic performance of students. The results of the findings indicated that students with parents with high economic status performed better academically than those students whose parents have low socioeconomic power. The study reviewed that poverty, poor education level of the parents and poor communication between home and the school as some of the factors that influence the attitudes of parents towards the education of their children. This finding is supported by Joseph, (2016) and Ghazi et al. (2013) whose findings indicated that socio-economic status of parents has a significant relationship with the academic achievement of their children. 


\subsubsection{Theme Six: Mother Tongue Interference}

The use of mother tongue in schools is considered as one of the reasons why students perform poorly in reading. According to most of the participants, most of the primary school students do not speak English, and they converse more both at home and in the school in either Hausa or Fulfulde which are their local dialects. A study carried out by Sa'ad and Usman, (2014) in Jigawa state indicated mother tongue interference and lack of qualified teachers as some of the factors responsible for poor performance of secondary school students in the English language. In a similar study, Adebayo, (2008) used a qualitative research approach to investigate the influence of mother tongue on the performance of junior secondary school students in North Central region of Nigeria. The findings indicated mother tongue, insufficient English teachers, lack of textbooks as some of the factors responsible for the poor performance of students in English language examination. Other studies in their quest to find out the causes of poor performance in the English language also found mother tongue interference as one of the reasons for poor performance in English language. Previous studies have validated the fact that mother tongue interferes with the reading abilities of students.

\subsection{Discussing Question Number Two: What Are Teachers' Perspectives of Student's Reading Achievement in The Classroom?}

The answer to the research question number two was very straightforward. The research question asked the teachers of their perspectives of students reading achievements in the classroom. Eighteen teachers said it was very poor while two said average. They further explained that reading is difficult and hard for the students. Comparing the participants answer on their students' reading achievement in the classrooms to the literature reviewed, some of the previous studies indicated that teachers' pedagogical practices could positively or negatively affect students' performances in the different school subjects (Abe, 2014). There is an indication in some studies that there is a significant impact teachers' content knowledge and pedagogical practices have on students' performances in the different subjects taught in the schools (Bold, et al. 2017). Evidence from a world bank funded research study in seven sub-Sahara African countries to find out why a large number of students graduate from the primary schools lacking basic skills in literacy and numeracy. The findings indicated that some of the teachers lack basic pedagogical skills and they do not have a mastery of the curricula. It is evident from the body of past research that there is an urgent need for the improvement of teachers' pedagogical skills and the mastery of the curriculum schools.

\subsection{Discussion on Research Question Number Three: What Are Teachers' Perspectives on The Role's Parents Play in Supporting the Reading Skills of Their Children?}

The participants in answering this question suggested the roles parents should play to enhance the academic skills of their children. Some of the suggestions include ensuring that their children have school supplies, helping them with their homework, advocating for the payment of their salaries and speaking the English language with their children. Several studies have indicated that parental involvement in the education of their children has a significant impact on the academic performance of the children particularly at the primary school level (Adewumi, 2015). Some of the studies mentioned ways that parents can be supportive of their children education. These 
suggestions include helping their children with homework, reading with and to their children, building an active communication with the school. Other include buying all the school supplies needed by the children and following up on their school performances.

\section{Conclusions and Recommendations}

Among the other factors, this research identified key militating dynamics which pony up the poor reading achievement of Pupils in public primary schools in Adamawa State. This was conducted from teachers' perspectives questionnaire and inquest. From the findings gathered through data collection, lack of payment of teachers' salaries is affecting their commitment which in turn impacts pupils negatively. Lack of qualified professional teachers into the schools in Adamawa state is another influencer for pupils poor reading. This finding is in line with findings from some studies which indicated better performances of students taught by professional subject teachers to students taught by non-professional teachers respectively. Based on the findings from this study, it is recommended that the government should pay teachers' salaries regularly to motivate them and increase their commitment to the teaching profession. Several studies have indicated the importance of teachers' commitment and motivation to the academic performances of their students. From the findings, lack of payment of teachers' salaries is affecting their commitment.

Another recommendation is for the state Ministry of Education to organize a professional development for all primary school teachers on phonics instructions. The recommendation is based on several findings that indicated that teachers' professional development has a positive impact on the academic performances of their students.

Also, some studies have also indicated the importance of phonics instruction at the kindergarten and primary level of education. Also, the government should employ only qualified professional teachers into the schools in Adamawa state. This recommendation is in line with findings from some studies which indicated better performances of students taught by professional subject teachers to students taught by non-professional teachers. Lastly, parents should be encouraged to get more involved in the education of their children. This recommendation is in line with findings from studies that revealed factors that influence parental involvement in their children education and also indicated the positive impact parental involvement has on the academic performance of their children.

\subsection{Research Implications}

For further research, the study should be repeated using larger population samples that will involve students, teachers, and parents. The study can also be extended to the other local government in the state. A further study is recommended to understand the effect of teachers' classroom practices on the performances of students in Adamawa state. There is also needed to research the extent to which low income affect parental involvement in the education of their children. The findings from the study will be beneficial to different NGO groups present in the Northeastern Nigeria that are striving to improve the literacy abilities of school-age children within the region, and it will also benefit teachers, the Ministry of Education, school leaders, parents and other educators. 


\title{
Acknowledgements
}

First, I express my profound gratitude to God Almighty for giving me the strength to complete this project. My sincere appreciation goes to Dr. Anastasia Liasidou, my supervisor for her constructive and prompt feedback throughout the research process. To my husband and daughter, I say thank you for your sacrifices, encouragement, and support during the period of my studies. Lastly, I want to extend my gratitude to Ashawa Moses who took his time to go through the manuscript and make the necessarily corrections and inputs.

\section{Appendices}

\section{Appendix A: Ethical Approval Form}

\author{
Appendix A: Ethical Approval Form \\ PARTICIPANT CONSENT FORM \\ Title of Research Project: Factors responsible for the poor reading achievement of Pupils in \\ Public Primary Schools in Yola- South and North Local Government Area of Adamawa State \\ Brief Description of Research Project, and What Participation Involves: \\ Purpose of the study: The purpose of the study is to understand the factors responsible for \\ poor reading achievement of primary school pupils in Yola South and North Local \\ Government of Adamawa State. \\ Research Method: The research will use phenomenological inquiry, a qualitative research \\ method approach. The phenomenological inquiry will enable the researcher to understand \\ teachers' perspectives of the factors that influence the reading abilities of primary school \\ students in Yola South and North Local Government of Adamawa State. \\ Participants: A total of 20 teachers will be selected from twenty schools within Yola and \\ South Local government area. Two teachers will represent a school. Posters will be placed \\ on the school walls with permission from the school principals of the selected schools. The \\ posters will stay on schools walls for two weeks. The intending participants can call the \\ researcher number that is on the poster. The participants are given two weeks to decide if \\ they wanted to be part of the study. After the two weeks, the researcher would initiate a \\ meeting with the individual participants to explain in a clear language the content of the \\ consent form. The participants are given a week to go through the consent form, fill it if the \\ participants still desire to be part of the study. The identity of the participants will not be \\ revealed to the school administrators or principals. The participants will be identified with \\ numbers in no particular order. \\ Sampling and Inclusion Criterion: Posters are placed on the walls of the randomly selected \\ school with the permission of the school Administrators/Principals. All the other criteria like \\ having a teaching experience of five years and above will all be on the poster. The number \\ on the poster belongs to the researcher who will do the recruiting. \\ Data collection: The teachers will be interviewed for about 40 minutes, and their viewpoints \\ will be audio taped and also handwritten by the researcher. The time of interview will not
}


exceed one hour. The researcher will conduct the interview process in a place jointly agreed by the participants and the researcher. The venue, date and interview timing will only be known by both researcher and the participants. The school administrators or principals will not know the identity of their staffs that volunteered to be part of the study. The researcher does not have any relationship with the school administrator or principal or any member of staff in the participant school. The interview questions will be semi structured with some extra probing questions to elicit richer data. The data collected will be stored in a personal computer and passworded. Since the interview process will take place after working hours, it might not be too comfortable because it is taking place after working hours. The findings from this study will benefit teachers in our community because the purpose of the study is to understand the factors responsible for the poor reading achievements of primary school students from a teacher's perspective. The identity of the schools and the participants will not be revealed during data analysis. Letters of the alphabet will be used to identify the schools in no particular order while the participating teachers will be given numbers for identity. The participants have the rights to withdraw from this study without prior notice to the researcher. The participants have a right to question the researcher legally if the terms of participation and usage of data collected are not adhered to by the researcher

Data analysis: The data will be typed nightly and stored in my computer, and a copy will also be stored in a flash drive gotten just for the purpose. The data will be coded, and common themes will be generated for the narration. The researcher will constantly approach the participants during data analysis to ensure that their viewpoints are correctly interpreted.

Data Usage: The data collected will be used to add to existing knowledge on the above topic and destroyed after the project is graded. Confidentiality and anonymity of the participants will be protected. The data will be stored in my personal computer and passworded.

Investigator Contact Details:

Name: Elizabeth Raymond

Department: Educational Leadership

University Address: Roehampton University

Postcode

Email: Elizabeth.Raymond@roehampton-online.com

Telephone: 08077400571

\section{Consent Statement:}

I am giving my consent to participate in this research. I do understand that my participation is voluntary and I am free to withdraw at any point without giving the reason for my withdrawer. I also, do understand that my role in this research will be treated with confidence and anonymity. My identity will not be revealed during the publication of the project findings and that the data will be collected and processed by the Data Protection Act 1998 and with the University's Data Protection Policy.

Name

Signature

Date

Please note: if you have a concern about any aspect of your participation or any other queries, please raise this with the investigator (or if the researcher is a student you can also contact the Director of Studies.) However, if you would like to contact an independent party, please contact the Head of Department.

Programme Director Contact Details:

Name: Dr. Vangelis Tsiligiris

Email: Vangelis.Tsiligiris@roehampton-online.ac.uk

Research Participant Advocate

Telephone: USA number 001-612-312-121 


\section{Appendix B}

\section{Sample of Interview questions and Orientation Protocol Orientation Protocol}

\section{Orientation Session}

Thank you for agreeing to meet with me. I am an educator like you and doing a Master program in Education Leadership. This project is part of my final school assignment. Today is to get to know you and give this consent form to you. Your signing the consent form gives me the go ahead to proceed with the interview session. I will want to explain the entire process to you. The researcher will explain in details the following:

1) The purpose of the study

2) The research method that will be used

3) The number of participants for the study

4) Sampling and Inclusion Criterion

5) Data collection

6) The participants' rights to withdraw from the study without prior notice to the researcher.

7) The participants' right to question the researcher legally if the terms of participation and usage of data collected are not adhered to by the researcher

8) The way the data will be analyzed

9) Data Usage and destruction after grading.

10) Protection of the confidentiality and anonymity of the participants

11) Giving of the consent form and a promise to come for it after two weeks.

\section{Opening of Interview Session}

Thank you for agreeing to be interviewed for the research project. As you already know my name is Elizabeth Raymond, and I am a teacher and a student. Can I have the consent form? Thank you for signing it.

I want you to know that I am committed to the information on the consent form you signed. Confidentiality and anonymity will be upheld. The information you will share with me will be used for research purpose, and your personal data or identity will not be revealed in the reporting. I will also be recording our conversation. This is to enable me to capture your responses appropriately. I hope you don't mind me recording our conversation? I will also take note. Can we start? Thank you once again

\section{Interview Questions}

1) How long have you taught in a Nigeria public school?

2) What ages of pupils have you taught?

3) Have you taught in public schools in other regions in Nigeria?

4) What do you believe are the causes of poor reading achievement among primary school pupils in Adamawa state?

5) As a teacher, what can you tell me about students reading attainment in the classrooms?

6) What reading strategies have you used as a teacher to help struggling readers in your classrooms? 
7) Can you share with me some strategies or effort your school is doing to help improve the reading achievements of your pupils?

8) Tell me ways you feel parents can help their children improve their reading achievements?

9) What partnership can happen between the school and the home to help these children improve in reading fluency?

10) What other group or organization do you think can contribute to providing support for these struggling readers?

11) As an experienced teacher that cares about children, what do you think?

- Other teachers can do to help these children?

- Parents can do to help these children?

- The society can do to help these children?

- The government and ministry of education can do to help these children?

Probing questions or Follow -Up questions

1) What makes you feel that way?

2) Can you tell me about your thinking on that?

3) Could you please tell me more about...

4) Tell me more about that.......

5) This is really interesting, please, tell me more

\section{Appendix C}

Transcribed Interviews and the process of theme development

\begin{tabular}{|c|c|c|}
\hline $\begin{array}{l}\text { Question number 4: What do you believe are } \\
\text { among primary school pupils in Adamawa stat }\end{array}$ & 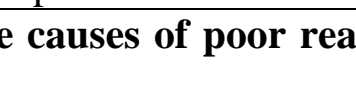 & g achievements \\
\hline Raw data & Codes & Emerged Theme \\
\hline $\begin{array}{l}\text { The government pays salaries after two to three } \\
\text { months, how do they expect us to be happy } \\
\text { teaching. Participant } 1 \\
\text { I do not go to work every day because I do not have } \\
\text { money to pay for my transportation. How do you } \\
\text { expect me to be happy teaching? Participant } 3 \\
\text { Lack of salary is affecting teachers' commitment to } \\
\text { their work. I am still going to teach because of the } \\
\text { fear of God and because my house is not far from } \\
\text { the school. Most of my colleagues do not come to } \\
\text { work because they say they do not have money for } \\
\text { transportation. Primary school teachers are } \\
\text { suffering. Students are also suffering. Participant } \\
20 \\
\text { Public school teachers have "I don't care" attitude } \\
\text { towards their teaching profession. You cannot } \\
\text { blame them. Their salaries are not regularly paid. } \\
\text { Participant } 5 \\
\text { Teachers are not motivated by the government. } \\
\text { Participant } 4\end{array}$ & $\begin{array}{l}\text { Do not go to work } \\
\text { daily. } \\
\text { Not happy at job } \\
\text { Lack of salary } \\
\text { responsible } \\
\text { Commitment to job } \\
\text { affected. } \\
\text { Negative attitude } \\
\text { affect students }\end{array}$ & $\begin{array}{l}\text { Lack of } \\
\text { commitment of } \\
\text { teachers to their } \\
\text { responsibilities }\end{array}$ \\
\hline
\end{tabular}


DOI: 10.5281/zenodo.3240967

\begin{tabular}{|c|c|c|}
\hline $\begin{array}{l}\text { How is this? Salaries are not paid. } \\
\text { The English has not been coming for three weeks } \\
\text { now. No English class. Participant } 6 \\
\text { Teachers are not motivated to teach with passion } \\
\text { because they are unhappy about the irregular } \\
\text { payment of their salaries. Participant } 7 \\
\text { Teachers are not motivated because of poor welfare } \\
\text { of the teachers. (Participants 18) } \\
\text { Lack of commitment on the side of the school } \\
\text { management and the teachers. (Participant } 9 \text { ) }\end{array}$ & $\begin{array}{l}\text { Not motivated. Not } \\
\text { committed } \\
\text { Unhappy due to } \\
\text { irregular payment of } \\
\text { salaries. Motivation } \\
\text { lacking. } \\
\text { Not motivated } \\
\text { Poor welfare } \\
\text { Lack of } \\
\text { commitment from } \\
\text { teachers and } \\
\text { government }\end{array}$ & \\
\hline \multicolumn{3}{|c|}{$\begin{array}{l}\text { Question number 4: What do you believe are the causes of poor reading achievements among } \\
\text { primary school pupils in Adamawa state? }\end{array}$} \\
\hline Raw data & Codes & Emerged Theme \\
\hline \multicolumn{3}{|c|}{$\begin{array}{l}\text { Question number 4: What do you believe are the causes of poor reading achievements among } \\
\text { primary school pupils in Adamawa state? }\end{array}$} \\
\hline Raw data & Codes & Emerged Theme \\
\hline $\begin{array}{l}\text { The textbooks my school gave to me are old } \\
\text { editions, and they are worn out. I have to use my } \\
\text { own money to buy current updated version. It is } \\
\text { what we are facing at the primary schools. The } \\
\text { teachers' textbooks are worn out and outdated. We } \\
\text { do not have instructional materials to make teaching } \\
\text { more attractive. Only committed teachers provide } \\
\text { those things for themselves. Remember we do not } \\
\text { have salaries so how do we provide them. } \\
\text { (Participant 20) } \\
\text { The school does not give us instructional materials } \\
\text { and the textbooks are worn out. Sometimes, I have } \\
\text { to borrow a textbook from the students. The } \\
\text { government does not care about public schools. } \\
\text { Their children are not here. Gone are the days when } \\
\text { both students and teachers get new books every } \\
\text { school } \\
\text { (Participant 4) } \\
\text { We lack textbooks and instructional materials. This } \\
\text { is a factor that can affect student performance. } \\
\text { (Participant 5) } \\
\text { The instructional materials are not adequate. } \\
\text { (Participant 7) } \\
\text { There is a lack of updated teaching instructional } \\
\text { materials at the lower primary level. (Participant 11) } \\
\text { Some pupils will learn better if we have instructional } \\
\text { materials to make the class more interesting. }\end{array}$ & $\begin{array}{l}\text { No instructional } \\
\text { materials } \\
\text { Lack } \\
\text { government } \\
\text { commitment } \\
\text { An indication that } \\
\text { things were not } \\
\text { like this some } \\
\text { years ago. }\end{array}$ & $\begin{array}{l}\text { Lack of } \\
\text { instructional and } \\
\text { learning materials }\end{array}$ \\
\hline
\end{tabular}




\begin{tabular}{|l|l|l|}
\hline & $\begin{array}{l}\text { Inadequate } \\
\text { instructional } \\
\text { materials. } \\
\text { Indication that } \\
\text { current textbooks } \\
\text { are not available } \\
\text { for teachers' use. } \\
\text { Importance of } \\
\text { instructional } \\
\text { materials. }\end{array}$ \\
\hline Question
\end{tabular}

Question number 4: What do you believe are the causes of poor reading achievements among primary school pupils in Adamawa state?

\begin{tabular}{|c|c|c|}
\hline Raw data & Codes & Emerged Theme \\
\hline $\begin{array}{l}\text { Another problem we have in the public schools is } \\
\text { that we have people teaching who are not trained as } \\
\text { teachers. They lack the skills to teach. } \\
\text { (Participant 20) } \\
\text { We do not have enough teachers that studied } \\
\text { English or related courses, so pupils do not receive } \\
\text { the right instruction in reading. } \\
\text { (Participant 1) } \\
\text { We have people that studied Survey at Diploma } \\
\text { level teaching at the school. We have a lot of non- } \\
\text { teachers teaching in the system. We that went to } \\
\text { Teacher colleges are trained to teach. We have a } \\
\text { problem in this state. It is not possible to get quality } \\
\text { teaching from people that are not trained. } \\
\text { (Participant 17) } \\
\text { In my school, we have only one teacher that read } \\
\text { English. Others do not have the knowledge base to } \\
\text { teach the subject. We need more subject teachers in } \\
\text { the system. (Participant } 8 \text { ) } \\
\text { Some people who are employed to teacher are not } \\
\text { qualified and they do not have teachers certificate. } \\
\text { ( Participant 9) } \\
\text { We lack English teachers in the system. } \\
\text { (Participant 13) } \\
\text { We have a lot of untrained teachers in the system. } \\
\text { This can affect students' performances in any of the } \\
\text { subject. (Participant 16) } \\
\text { Teachers that are not trained are in the system and } \\
\text { they are not committed to the profession. } \\
\text { Government should stop employing such into the } \\
\text { system. (Participant 14) }\end{array}$ & $\begin{array}{l}\text { Presence of } \\
\text { untrained teachers. } \\
\text { Untrained teachers } \\
\text { may lack the skills } \\
\text { to teach. } \\
\text { Inadequate English } \\
\text { teachers }\end{array}$ & $\begin{array}{l}\text { Inadequately } \\
\text { qualified teachers }\end{array}$ \\
\hline
\end{tabular}


Question number 4: What do you believe are the causes of poor reading achievements among primary school pupils in Adamawa state?

\begin{tabular}{|c|c|c|}
\hline Raw data & Codes & Emerged Theme \\
\hline $\begin{array}{l}\text { Students are sent to school without food. A child } \\
\text { that is hungry cannot learn. Participant } 2 \\
\text { Some parents do not buy textbooks for their } \\
\text { children. No pencils, no exercise books. How can } \\
\text { that child learn? Participant } 10 \\
\text { Parents demand that you promote their children } \\
\text { that did not pass to the next class. I have a situation } \\
\text { four years ago when a father demanded that I } \\
\text { should promote his child to Primary Five. That } \\
\text { child cannot even spell simple three letter word. I } \\
\text { wrote a word on the board in the presence of the } \\
\text { headmaster and asked the boy to read it, and the boy } \\
\text { could not read. The headmaster wondered how he } \\
\text { made it to Primary four. Parents do not help us at } \\
\text { all. Participant } 20 \\
\text { Some of these children come to school without } \\
\text { food. Their nutrition is poor. How can a child learn } \\
\text { when he/she is hungry? Participant } 8 \\
\text { Some of the students come late to school, and some } \\
\text { students do not come at all, and when you ask them, } \\
\text { it was their parents that took them to the farm to } \\
\text { work for them or asked them to assist in their petty } \\
\text { businesses. Parents are not encouraging teachers at } \\
\text { all. Participant } 16 \\
\text { Parents do not supervise or ensure their children } \\
\text { read or study at home. Home support is very vital } \\
\text { to a child's performance. Participant } 10 \\
\text { It is poverty that is affecting the parents' attitude } \\
\text { towards the education of their children, and poverty } \\
\text { is the reason why some parents cannot supply the } \\
\text { educational need of their children. (Participant } 18 \text { ) }\end{array}$ & $\begin{array}{l}\text { Children go to } \\
\text { school without } \\
\text { food. Children may } \\
\text { not learn } \\
\text { Students need to } \\
\text { help with family } \\
\text { business and it } \\
\text { negatively impact } \\
\text { on their academics. } \\
\text { Home support is } \\
\text { vital a } \\
\text { Poverty is a } \\
\text { contributing factor. }\end{array}$ & $\begin{array}{l}\text { Impact of socio } \\
\text { economic status } \\
\text { of parents on the } \\
\text { education of their } \\
\text { children }\end{array}$ \\
\hline
\end{tabular}


Question number 4: What do you believe are the causes of poor reading achievements among primary school pupils in Adamawa state?

Raw data
Our students speak the Hausa or Fulani language a
lot. Some of them cannot speak the English
language. It is one of the reasons why it is difficult
for them to read. Participant 20

The mother tongue is interfering with their reading. Students find it difficult to speak English. Even we the teachers talk to them in Hausa or Fulani. We are not helping them too. Participant 2 A child that cannot speak English will find it difficult reading. The students speak too much vernacular in the school. Participant 4

The majority of the public school students cannot speak English; they do not understand English and cannot read in English. Participant 3

Most of our primary school students speak in their local dialect. To speak in English is difficult. (participant 16)

Mother tongue interferes with their ability to read and write in English. Participant 17

The Hausa and Fulani language dominate the spoken language among our pupils. This could also be what is affecting their reading. (Participant 5)

The local dialect is affecting the use of English language. We all speak it with our pupils. At the primary education, speaking English is difficult for the pupils. They will get better at the secondary school.

( Participant 10)

\begin{tabular}{|c|c|}
\hline Codes & Emerged Theme \\
\hline $\begin{array}{l}\text { Dominance of local } \\
\text { language }\end{array}$ & \\
\hline $\begin{array}{l}\text { Conversation in } \\
\text { English language is } \\
\text { difficult. }\end{array}$ & \\
\hline $\begin{array}{l}\text { Dominance of local } \\
\text { dialect is perceived } \\
\text { to be one of the } \\
\text { factors affecting } \\
\text { reading } \\
\text { performance. } \\
\text { Indication that } \\
\text { Primary school } \\
\text { pupils cannot speak } \\
\text { English. }\end{array}$ & $\begin{array}{l}\text { Mother tongue } \\
\text { interference }\end{array}$ \\
\hline $\begin{array}{l}\text { Dominance of the } \\
\text { local dialect in the } \\
\text { students school } \\
\text { conversation. } \\
\text { Mother tongue } \\
\text { inference may affect } \\
\text { reading } \\
\text { performance. } \\
\text { Dominance of the } \\
\text { local dialect. } \\
\text { Dominance of the } \\
\text { local dialect }\end{array}$ & \\
\hline
\end{tabular}

Question number 5: As a teacher, what can you tell me about students reading attainment in the classrooms?

\begin{tabular}{|l|l|l}
\hline Raw data & Codes & Ratio \\
\hline
\end{tabular}




\begin{tabular}{|c|c|c|}
\hline $\begin{array}{l}\text { It is a difficult task to teach students how to read. } \\
\text { Reading is difficult and challenging for the students. } \\
\text { Participant } 1 \\
\text { Majority of the public primary school students do } \\
\text { not understand English and cannot read. Reading } \\
\text { attainment of the students is very poor. Participant } 3 \\
\text { Very poor. They cannot speak English. Their local } \\
\text { dialect is interfering with learning in English } \\
\text { language. Participant } 4 \\
\text { Very poor. Participant } 5 \\
\text { It is difficult and challenging. Participant } 6 \\
\text { Very poor and difficult. Some of the factors we } \\
\text { discussed are responsible. Participant } 7 \\
\text { My students are not so bad. I will say average. } \\
\text { Participant } 10 \\
\text { Very poor. The English teacher has not being } \\
\text { coming for one month now. You cannot blame her. } \\
\text { No money for transportation. Participant } 11 \\
\text { Very poor. Student cannot pronounce words } \\
\text { correctly. Participant } 12 \\
\text { I will say average but they still have a lot to do. I will } \\
\text { try my best. Participant } 13 \\
\text { Very poor. The parents of the public school pupils } \\
\text { do not provide English textbooks. Participant } 14 \\
\text { Very poor. The pupils are not interested in learning. } \\
\text { They do not have writing and reading materials. } \\
\text { Participant } 15 \\
\text { Very poor. They do not study at home. Participant } \\
16 \\
\text { Very poor. Students do not challenge teachers by } \\
\text { way of asking questions. Participant } 17\end{array}$ & $\begin{array}{l}\text { Very poor } \\
\text { Very poor } \\
\text { Difficult and } \\
\text { challenging } \\
\text { Very poor and } \\
\text { difficult } \\
\text { Average } \\
\text { Very poor } \\
\text { Very poor } \\
\text { Average } \\
\text { Very poor } \\
\text { Very poor } \\
\text { Very poor } \\
\text { Very poor }\end{array}$ & $\begin{array}{l}18 \text { very poor : } 2 \\
\text { average }\end{array}$ \\
\hline
\end{tabular}

\section{References}

[1] Adeniji, A., Sam, Y., \& Omale, A. Teaching reading comprehension in selected primary schools in Oyo State, Nigeria. Deew Publishing; 2010, 12.

[2] Geske, A., \& Ozola, A. Factors influencing reading literacy at the primary school level Problems of Education in the 21st Century Vol 6, 2008, 46-49.

[3] Cimmiyotti, C. Impact of Reading Ability on Academic Performance at the Primary Level. Master's Theses and Capstone Projects. 2013, 127.

[4] Reutzel, D. R. Early literacy research: Findings primary-grade teachers will want to know. The Reading Teacher, Vol. 69, N0. 1, 2015, 14-24.

[5] Tong, X, Deacon, S, Cain, K, Kirby, J, \& Parrila, R. Morphological Awareness: A Key to Understanding Poor Reading Comprehension in English, Journal Of Educational Psychology, Vol.103, N0. 3, 2011, 523-534. 
[6] Pfost, M., Dörfler, T. \& Artelt, C. Reading competence development of poor readers in a German elementary school sample: an empirical examination of the Matthew effect model, Journal of Research in Reading. Vol. 35, N0.4, 411-426, 2012.

[7] Elwér, Å. Early predictors of reading comprehension difficulties. 2014.

[8] Dunne, M. Humphreys, S. Dauda, M., Kaibo, J. and Garuba, A. Adamawa State Primary Education Research, Access, quality, and outcomes, with specific reference to gender.2013.

[9] UNESCO. Adult and youth literacy. Available at: http://www.uis.unesco.org/literacy/Documents/fs26-2013-literacyen. Pdf (Accessed 27/2/2017).

[10] Amnesty International. Keep away from schools or we'll kill you: Right to education under attack in Nigeria'. Amnesty International London. 2013.

[11] Maynard, M. Methods, practice and epistemology: The debate about feminism and research. Researching women's lives from a feminist perspective. 1994, Vol.10, .26.

[12] Creswell, J.W. Research design: Qualitative-quantitative, and mixed methods approach, Sage Publications. 2014.

[13] Creswell, J.W. Qualitative inquiry and research design: Choosing among five approaches (2nd edition) T housand Oaks,. CA: Sage Publications. 2007.

[14] Punch, K. F. Introduction to Research Methods in Education. Sage publications. 2007.

[15] Gill, P., Stewart, K., Treasure, E. and Chadwick, B.Methods of data collection in qualitative research: interviews and focus groups. British dental journal, 2018, Vol. 204, N0. 6, 291-295. Available at: http://www.nature.com/bdj/journal/v204/n6/pdf/bdj.2008.192.pdf (Accessed 27/3/2017).

[16] Jamshed, S. Qualitative research method-interviewing and observation. Journal of basic and clinical pharmacy. 2014, Vol.5, No.4, 87.

[17] Seidman, I. Interviewing as qualitative research: A guide for researchers in education and the social sciences. Teachers college press. 2013.

[18] Saldaña, J. The coding manual for qualitative researchers. Sage Publications. 2017.

[19] Cornelius-Ukpepi, B.U., Ndifon, R.A. and Enukoha, O.I. Correlates of Examination Malpractice and Academic Performance of Primary School Students in Cross River State, Nigeria. American Journal of Social Issues and Humanities. 2014, Vol.2, No. 6.

[20] Kiplagat, P., Role, E. and Makewa, L.N. Teacher commitment and mathematics performance in primary schools: A meeting point!. International Journal of Development and Sustainability. 2012, Vol. 1, No.2, 286-304.

[21] Abudu, A. and Gbadamosi, R. Relationship between teacher's attitude and student's academic achievement in senior secondary school chemistry. A case study of Ijebu-Ode and Odogbolu Local Government Area of Ogun state. Woodpecker Journal of Educational Research 2014, Vol. 3, No.3, 035-043.

[22] Denessen, E., Vos, N., Hasselman, F. and Louws, M. The relationship between primary school teacher and student attitudes towards science and technology. Education Research International, 2015.

[23] Oredein, A. and Awodun, A. Impact of Teachers' Motivational Indices on Science Students' Academic Performance in Nigerian Senior Secondary Schools. International Education Studies, 2013, Vol. 6, No.2, 49.

[24] Ofoegbu, F. Teacher Motivation: A Factor for Classroom Effectiveness and School Improvement in Nigeria College Student Journal, 38, (1) pp. 81-89, Academic Search Complete, EBSCOhost, (accessed 3/10/2017).

[25] Ma, X., \& Crocker, R. Provincial effects on reading achievement. The Alberta Journal of Education Research, 2016, Vol. 53, No.2, 87-109.

[26] National Research Panel, Teaching children to read: An evidence-based assessment of the scientific research literature on reading and its implications for reading instruction. Washington, DC: National Academy Press, 2014. 
[27] Don-Ezenne, N. Identification and Analysis of Problem of Word Recognition in Reading among JSS Students in Gwgwalada and Kwali Area Councils of Federal Capital Territory, Abuja IOSR Journal of Research \& Method in Education (IOSR-JRME) e-ISSN: 2320-7388,p-ISSN: 2015, 2320-737X 4 (5).

[28] Okebukola, w. Literacy and Reading in Nigeria A Journal of the Reading Association of Nigeria.2014, Vol. 12, No.1.

[29] Akptan, C.P. and Ita, A.A. Teachers professional development and qualify universal basic education in Lagos State, Nigeria. Global Journal of arts, Humanities and Social Sciences,2015, Vol 3, No. 65, 75.

[30] Alade, O.M. and Odebode, M.O.O. An Assessment of the Impact of the Teachers' Professional Development Programme under Lagos "Eko" Secondary Education Project in Lagos State. Journal of Educational and Practice, 2014 Vol. 5, .19.

[31] Olayinka, A.R.B. Effects of Instructional Materials on Secondary Schools Students' Academic Achievement in Social Studies in Ekiti State, Nigeria. World Journal of Education,2016, Vol. 6, No.1, 32.

[32] Fakeye, D. Teachers' Qualification and Subject Mastery as Predictors of Achievement in English Language in Ibarapapa Division of Oyo State, Global Journal of HUMAN SOCIAL SCIENCE ,2012, Vol.12, No.3.

[33] Oselumese, B. and Omoike, D. Influence of Qualification on Teachers' Job Performance in Secondary Schools in Edo State A Journal of the Faculty of Education, Ambrose Alli University, EKpoma,2015. Available at http://foeaau.com/?p=871 (Accessed 3/10/2017).

[34] Onyancha, M. and Newton, M. The influence of parents' socio-economic status on students' academic performance in public secondary schools in Keumbu Division,2015, Kisii County, Ke3nya.

[35] Joseph, V.I. Relationships among Parents' educational Level, Income, Academic Adjustment and Performance of Senior Secondary School Students In Kaduna Metropolis, Nigeria, 2016, (Doctoral dissertation).

[36] Ghazai, C., Claassen Thrush, E., Soto-Peña, M., Whang, C. and Luschei, T.F. Teacher Voice in Global Conversations around Education Access, Equity, and Quality. In FIRE: Forum for International Research in Education, 2017, Vol. 4, No., 2.

[37] Sa'ad, T.U. and Usman, R.The Causes of Poor Performance in English Language among Senior Secondary School Students in Dutse Metropolis of Jigawa State, Nigeria. IOSR Journal of Research \& Method in Education, 2014, Vol. 4, No.5, 41-47.

[38] Abe, T.O. The effect of teachers' qualifications on students' performance in mathematics. Sky Journal of Educational Research, 2014, Vol. 2, No.1, 10-14.

[39] Bold, T., Filmer, D., Martin, G., Molinad, E., Rockmore, C., Stacy, B., Svensson, J. and Wane, W. What do teachers know and do? does it matter? Evidence from primary schools in Africa, 2015.

[40] Adewumi, B. High expectations: black professional parents' aspirations for their children (Doctoral dissertation, University of Kent). 2015.

\footnotetext{
*Corresponding author.

E-mail address: elizabeth.raymond@ aun.edu.ng
} 